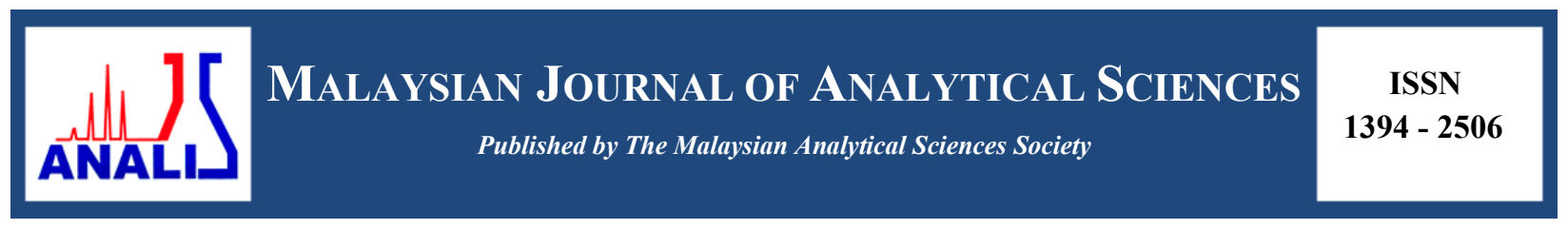

\title{
INFLUENCE OF ALKALI TREATMENT ON PHYSICO-CHEMICAL PROPERTIES OF MALAYSIAN BAMBOO FIBER: A PRELIMINARY STUDY
}

\author{
(Pengaruh Rawatan Alkali terhadap Sifat-sifat Fizikal-Kimia Serat Buluh Malaysia: Satu Kajian \\ Awal)
}

Foo Sheng Tong ${ }^{1 *}$, Siew Choo Chin ${ }^{1,2}$, Mohd Tamizi Mustafa ${ }^{4}$, Huei Ruey Ong ${ }^{3}$, Md. Maksudur Rahman Khan ${ }^{2,3}$, Jolius Gimbun ${ }^{2,3}$, Shu Ing Doh ${ }^{1}$

${ }^{I}$ Faculty of Civil Engineering \& Earth Resources

${ }^{2}$ Centre of Excellence for Advanced Research in Fluid Flow (CARIFF)

${ }^{3}$ Faculty of Chemical \& Natural Resources Engineering

University Malaysia Pahang, 26300 Gambang, Pahang, Malaysia

${ }^{4}$ Kualiti Kayu dan Hasil Bukan Kayu, Bahagian Keluaran Hutan,

Forest Research Institute of Malaysia, 52109 Kuala Lumpur, Malaysia

"Corresponding author: tongfoosheng@hotmail.com

Received: 4 December 2016; Accepted: 1 December 2017

\begin{abstract}
In the present study, the effect of alkaline treatment on the morphology and physico-chemical properties of Malaysian bamboo fibers was elucidated. The fibers were extracted from raw bamboo culm using alkaline solution with concentrations of 0 and 10 wt $\%$ at 24 hours and followed by roller milling techniques. The treated and untreated fibers were characterized by Fourier transform infrared spectroscopy (FTIR), thermogravimetric analysis (TGA) and scanning electron microscope (SEM). Apart from that, the mechanical properties of single fiber were also investigated. It was found that the tensile strength and modulus of the alkali-treated fiber were improved by 45.6 and $72 \%$, respectively, compared to the untreated fiber. The surface morphology of the treated fiber was improved in which the surface roughness has been reduced significantly as proven in SEM. The FTIR and TGA data suggested that alkaline treatment gradually removed the lignin and hemicellulose. These findings highly recommended that, local bamboo fiber could be used as a reinforcement agent for composite making.
\end{abstract}

Keywords: alkaline treatment, bamboo fiber, natural fiber, natural fiber composite, roller milling techniques

\section{Abstrak}

Dalam kajian ini, kesan rawatan alkali terhadap sifat morfologi dan fizikokimia gentian buluh Malaysia telah dijelaskan. Serat telah diambil dari laras buluh mentah dengan menggunakan larutan alkali dengan kepekatan 0 dan $10 \%$ pada 24 jam dan diikuti dengan teknik penggilingan roller. Serat yang dirawat dan tidak dirawat dicirikan oleh spektroskopi transformasi Fourier (FTIR), analisis termogravimetrik (TGA) and mikroskop imbasan elektron (SEM). Selain itu, sifat mekanik serat tunggal juga disiasat. Keputusan telah didapati bahawa kekuatan tegangan dan modulus serat yang dirawat alkali telah meningkat sebanyak 45.6 dan $72 \%$, berbanding dengan serat yang tidak dirawat. Morfologi permukaan serat yang dirawat telah diperbaiki dengan kekasaran permukaan berkurangan dengan nyata, seperti yang dibuktikan oleh SEM. Data FTIR dan TGA mencadangkan rawatan alkali telah menghilangkan lignin dan hemiselulosa secara beransur-ansur. Penemuan ini sangat disyorkan bahawa, serat buluh tempatan boleh digunakan sebagai ejen tetulang untuk pembuatan komposit.

Kata kunci: rawatan alkali, serat buluh, serat semulajadi, komposit gentian semulajadi, teknik penggilingan roller 


\section{Introduction}

Synthetic fiber reinforced polymer (FRP) composite is an advanced external strengthening material which used to address the structurally deficient reinforced concrete (RC) member in the building industry. The most common type of artificial fibers in practice nowadays are made of glass, nylon, aramid, or carbon fiber. The efficient performance of a composite material of RC component has been witnessed by a number of researchers and practicing engineers. However, the production process of artificial fiber is adversely affecting the environment by consuming huge amount of fossil fuel as energy, releasing enormous carbon dioxide, causing heavy environmental loads, in addition to the high production cost. In order to achieve the economical, eco-friendly and renewable natural resource requirements, the investigation of various natural fibers as a potential substitution to the artificial fiber have been conducted tremendously [1]. It was found that the introduction of the natural fiber as reinforcement in polymer matrix composites (PMCs) is capable to enhance the mechanical properties and performance of virgin materials [2].

The benefits of natural fiber are renewable, recyclable and biodegradable in nature, low cost, light in weight and density, high specific stiffness and mechanical properties as well as low abrasion to manufacturing equipment [3]. The applications of cellulose are diverse, for instance, civilian construction, paper and pulp, furniture, packaging and storage, and automotive industry [3-6]. Nonetheless, it was found that not all the natural fibers are suitable to be utilized as reinforcement in composites. The development of agriculture is one of the greatest threat to the tropical forests. By considering the context of preserving the biodiversity, the plants that can be harvested several times in a growing cycle are the most favorable [7].

Bamboo fiber has been identified as the most attractive reinforcement material [8,9]. The function of bamboo ranged for household goods (furniture, chopsticks, handicraft, and textiles) and industrial applications. Bamboo is a common construction material that is utilized by mankind. In China, it is usually employed as a temporary exterior structural member such as scaffolding and housing. Bamboo sticks were added to concrete to improve the flexural and compressive strength [10]. Bamboo fibers were distributed into concrete to upgrade the concrete strength [11]. Bamboo fiber is also recognized as a typical natural composite material which offering extraordinary benefits over other natural fibers [12]. It is one of the fastest growing woody plants due to its unique rhizome-dependent system. The complete recovery growth period of bamboo can be done within two to three years prior to utilize. Moreover, the productivity of an acre of bamboo is greater than cotton about 10 times [13]. In Malaysia, where a tropical rainforest climate is all year round apparently, the accessibility and abundant availability of economical bamboo fibers are addressing the sustainable technology which can solve the disadvantages of the synthetic fibers. The mechanical properties of bamboo fiber are advantageous primarily because of its unidirectional fiber arrangement in the tissue and cellulose being its major constituent [14]. The unidirectional fiber consisting of parallel and long cellulose that embedded in ground tissues in ligneous matrix form [1].

All of the aspects of bamboo fiber have fulfil the latest material of structural upgradation criterion [11]. Yet, there were not enough studies had been conducted on the use of bamboo fiber as reinforcement to enhance the behaviour of the RC members externally. Most of the investigation of natural fibers as structural reinforcement is focused on kenaf, jute and sisal fibers [15 - 17]. The present study aims to study the influence of the alkaline treatment on physical-chemical properties of local bamboo fiber. Besides that, the effect of alkaline treatment on the mechanical properties of fibers was also elucidated.

\section{Materials}

\section{Materials and Methods}

The local bamboo species, Gigantochloa scortechinii Gamble of age range from three to five years old were used due to its commercialized viable and high strength feature. The raw bamboo culms were harvested by the laborers at the tropical forest in Raub district, Pahang, Malaysia. The obtained bamboo culms were delivered and stored in the shade at Non-wood Product Workshop at Forest Research Institute Malaysia (FRIM) which situated at Kepong, Selangor Darul Ehsan.

\section{Extraction of fibers}

The bamboo culms were cleaved using heavy-duty bamboo splitters into strips in approximately $30 \times 15 \times 1500$ $\mathrm{mm}$. The aqueous $\mathrm{NaOH}$ solution was prepared by dissolving the $\mathrm{NaOH}$ pellets in distilled water. The bamboo 
strips were treated with $10 \% \mathrm{NaOH}$ solution for 24 hours at ambient temperature. On the other hand, another batch of bamboo strips was immersed under the distilled water for 24 hours, served as control specimens. The alkalitreated bamboo strips were washed and immersed in the distilled water for 12 hours. Then the bamboo strips were placed into the mill roller machine to obtain the fibers and remove the impurities. The bamboo fibers were produced during the milling process. Then, the bamboo fibers were rinsed with distilled water several times to remove the alkaline content followed by examining using Universal Indicator Paper. The fiber with a pH of 6 was dried in an electrical oven at $60{ }^{\circ} \mathrm{C}$ for 24 hours. The fibers were stored in a desiccator with silica gel prior to characterization after drying in the oven. Figure 1 depicts macroscopic photographs of alkali treated bamboo fibers.

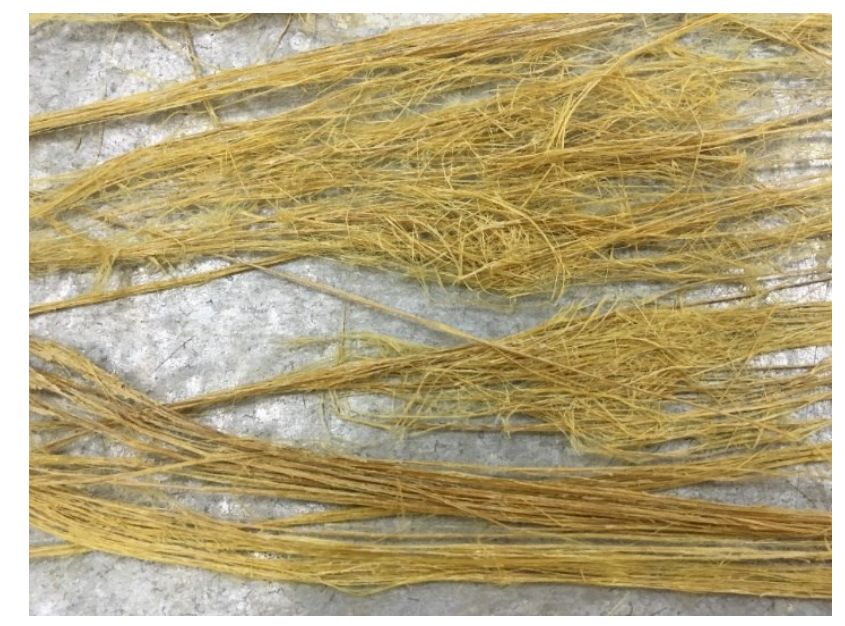

Figure 1. Macroscopic photograph of alkali treated bamboo fibers

\section{Characterization: Single fiber tensile test}

Ten (10) single fiber specimens were prepared according to ASTM C1557-14 standard. The determination of tensile strength and modulus of bamboo fibers was carried out at an ambient temperature of $24.9{ }^{\circ} \mathrm{C}$ with a relative humidity of $55 \%$. The specimens for testing were prepared by mounting a single fiber on a paper frame with a span length of $25.4 \mathrm{~mm}$. A vicinity in diamond shape of length equivalent to the gauge length was cut out in the middle of the mounting tab. Both ends of the fiber were glued on the paper with epoxy based adhesives. The tests were conducted using an Instron $50 \mathrm{kN}$ Blue Hill 3369 Universal Testing Machine (UTM). The crosshead speed was recorded at $0.48 \mathrm{~mm} / \mathrm{min}$. Both sides of the mounting tab had been cut at mid-gauge to release the fiber specimen before testing. The average diameter of the bamboo fiber was measured directly from the images on projection screen using an optical microscope MarVision MM 320. A total of three measuring points was taken at different locations along the gauge length of each fiber specimen. The average diameter was used to calculate the average cross-sectional area of the bamboo fiber by assuming that the fibers are in cylindrical shape. The diameters of the alkali treated bamboo fibers were in the ranged of $90-580 \mu \mathrm{m}$. In contrast, the diameter of the untreated fibers was ranged from $120-650 \mu \mathrm{m}$.

\section{Scanning electron microscope}

The surface morphology and microstructure of alkali-treated and raw bamboo fibers were examined using Hitachi (Japan) TM3030 Plus Benchtop Scanning Electron Microscope (SEM).

\section{Fourier transform infrared spectroscopy}

The Fourier transformed infrared spectrum of the bamboo fibers were performed using a Thermo Scientific Model Smart Performer attenuated total reflectance (ATR) accessory of Ge crystal, attach to a Thermo Scientific spectrophotometer (Model Nicolet iS50) with a single bounce. The wavenumber range of $500-4000 \mathrm{~cm}^{-1}$ with a resolution of $4 \mathrm{~cm}^{-1}$ and an average of 32 scans per minute were adopted. The bamboo fibers were ground into powder form before use in this characterization. 


\section{Thermogravimetric analysis}

The thermal stability of alkali-treated and untreated bamboo fibers were examined by the thermogravimetric analyzer (STA7000, Hitachi). The equipment was programmed under nitrogen atmosphere in the temperature range of 30 to $800^{\circ} \mathrm{C}$ at a heating rate of $10^{\circ} \mathrm{C} / \mathrm{min}$ and purge rate of $60 \mathrm{~mL} / \mathrm{min}$. The percentage of weight loss of the sample was calculated as follows:

$$
\text { Percentage of weight loss }=\left(\mathrm{W}_{1}-\mathrm{W}_{2}\right) / \mathrm{W}_{1} \times 100 \%
$$

where, $\mathrm{W}_{1}=$ Sample weight before testing and $\mathrm{W}_{2}=$ Sample weight at any given temperature.

\section{Tensile properties}

\section{Results and Discussion}

The tensile properties of raw and alkali-treated bamboo fibers are summarized in Table 1. It can be seen that, all the tested fibers failed. Bamboo fiber possessed a comparable strength to that of the artificial glass fibers as reported in the previous study [18]. Both tensile strength and modulus of the bamboo fibers were improved after the alkaline treatment. The highest tensile strength of the alkali-treated fiber was $368.33 \mathrm{MPa}$ in contrast to the raw fiber of $252.93 \mathrm{MPa}$. On the other hand, the average tensile modulus of raw and alkali-treated bamboo fibers was 10.89 and $27.93 \mathrm{GPa}$, respectively. A maximum enhancement of tensile strength was obtained approximately $115.4 \mathrm{MPa}$ or $45.6 \%$ is accomplished by $\mathrm{NaOH}$ treatment. Besides that, an increased in tensile modulus $(23.14 \mathrm{GPa}$ or $72 \%)$ was also established by the alkaline treatment. The improvements of the tensile properties had agreed with the previous study [3], due to the cementing materials like lignin and hemicellulose were eliminated during the alkaline treatment, which leads to an increment of the effective fiber surface area and roughness.

Table 1. Tensile properties of tested bamboo fibers

\begin{tabular}{lcc}
\hline \multirow{2}{*}{ Properties } & \multicolumn{2}{c}{ Bamboo Fibers } \\
\cline { 2 - 3 } & Untreated & Treated \\
\hline Ultimate Tensile Strength (MPa) & 252.93 & 368.33 \\
Average Tensile strength (MPa) & $140.10 \pm 22.26$ & $267.44 \pm 51.89$ \\
Ultimate Tensile Modulus (GPa) & 32.10 & 55.24 \\
Average Tensile Modulus (GPa) & $10.89 \pm 2.6$ & $27.93 \pm 5.97$ \\
\hline
\end{tabular}

\section{Surface morphology analysis}

The surface morphology of alkali-treated and untreated bamboo fibers are presented in Figure 2. Referring to Figure 2(a), the surface of the untreated fiber was covered by a superficial layer of impurities, which may include lignin, pectin, and other debris. On the contrary, most of the hemicellulose, lignin and other extractives were removed from the alkali-treated fiber surface (Figure 2(b)), which led to the formation of effective fiber surface attached with some tiny fissures and joints [1]. The increased in the cleanness and the smoothness of the fiber surface promotes the bonding reaction and interlocking adhesion which increased the adhesion of fiber-matrix due to the hydroxyl groups' exposure to the matrix. Furthermore, the separation of cemented fibers reduced the fiber diameter, resulting to a higher aspect ratio [1]. 


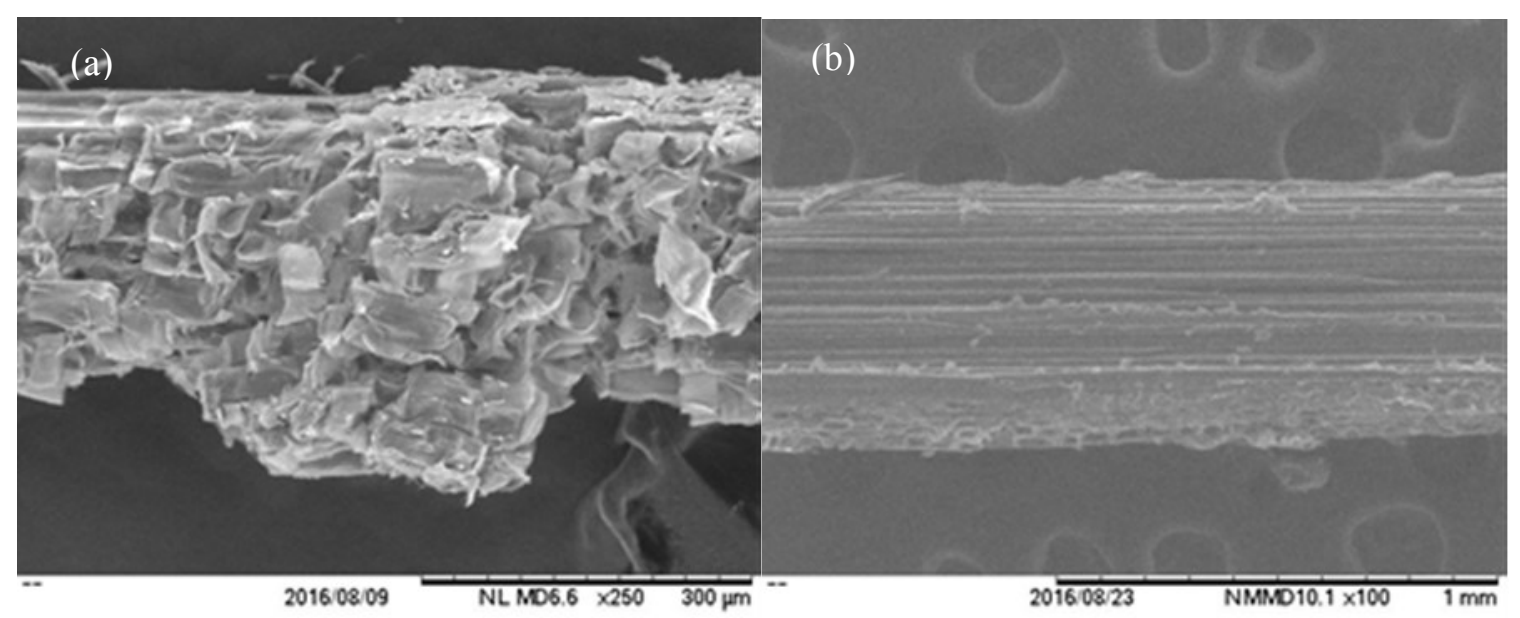

Figure 2. SEM images for longitudinal-section of (a) raw and (b) alkali-treated bamboo fiber

\section{FTIR analysis}

A comparison of the FTIR spectra of the alkali-untreated and treated bamboo fibers are illustrated in Figure 3. Multi part of the samples were represented by a number of absorption peaks. The comparison between the spectra were established on the relative intensity of the peaks, taking as the band at $897 \mathrm{~cm}^{-1}$, which attributed to C-O stretching vibration of amorphous cellulose, which indicates the $\beta$-glycosidic linkage between the monosaccharides $[1,19]$. The absorption peak at 1403 and $1140 \mathrm{~cm}^{-1}$ were the typical peak of cellulose in the natural fiber. The broad characteristics band of hydrogen bonded $(\mathrm{O}-\mathrm{H})$ stretching vibration can be seen from the wavenumber ranged from $3665-3013 \mathrm{~cm}^{-1}$ [3], the peak occurred at $3338.42 \mathrm{~cm}^{-1}$. While this peak was shifted to $3338.38 \mathrm{~cm}^{-1}$ after $\mathrm{NaOH}$ treatment. This phenomenon could be explained by the rising of hydroxyl group due to alkali-sensitive material is wiped off during treatment. The vibration peak at approximate of $1513.05 \mathrm{~cm}^{-1}$ was attributed to the stretching vibrational of pectin and hemicellulose and $2987.14 \mathrm{~cm}^{-1}$ was corresponding to the stretching of aromatic rings and alkane $(\mathrm{C}-\mathrm{H})$ stretching vibration in methyl and methylene, whereas for the alkali-treated fiber, this peak was decreased and moved to $2985.14 \mathrm{~cm}^{-1}$, caused by the removal of cementing materials. The raised peak at $1604 \mathrm{~cm}^{-1}$ could be defined by the presence of lignin. The absorption band from the range of $1765-1612 \mathrm{~cm}^{-1}$ was derived from the vibrational stretching of unconjugated carbonyl stretching $(\mathrm{C}=\mathrm{O})$ of pectin and hemicellulose. This band was decreased in the alkali-treated fiber IR spectrum, which could be due to the partial removal of lignin and hemicelluloses. Additionally, the vibrational stretching at the range of $1267-1239 \mathrm{~cm}^{-1}$ which attributed to the C-O of acetyl functional groups in the hemicelluloses and lignin was reduced during the $\mathrm{NaOH}$ treatment. The ester bond of raw fiber at $1033.27 \mathrm{~cm}^{-1}$ also showed the high C-O or C-C stretching of lignin and hemicellulose for raw bamboo fiber. The remarkable reduction in the intensity of the bamboo fiber after alkaline treatment indicates that the impurities and hemicellulose of the fiber surface were partially eliminated by the $\mathrm{NaOH}$ treatment, with no new functional groups are introduced in the cellulose molecules. These improvements are consistent with the observation of the alkali-treated fiber surface from the SEM micrographs, which indicated a reduction of cementing materials as reported by previous studies $[1,2,7]$. 


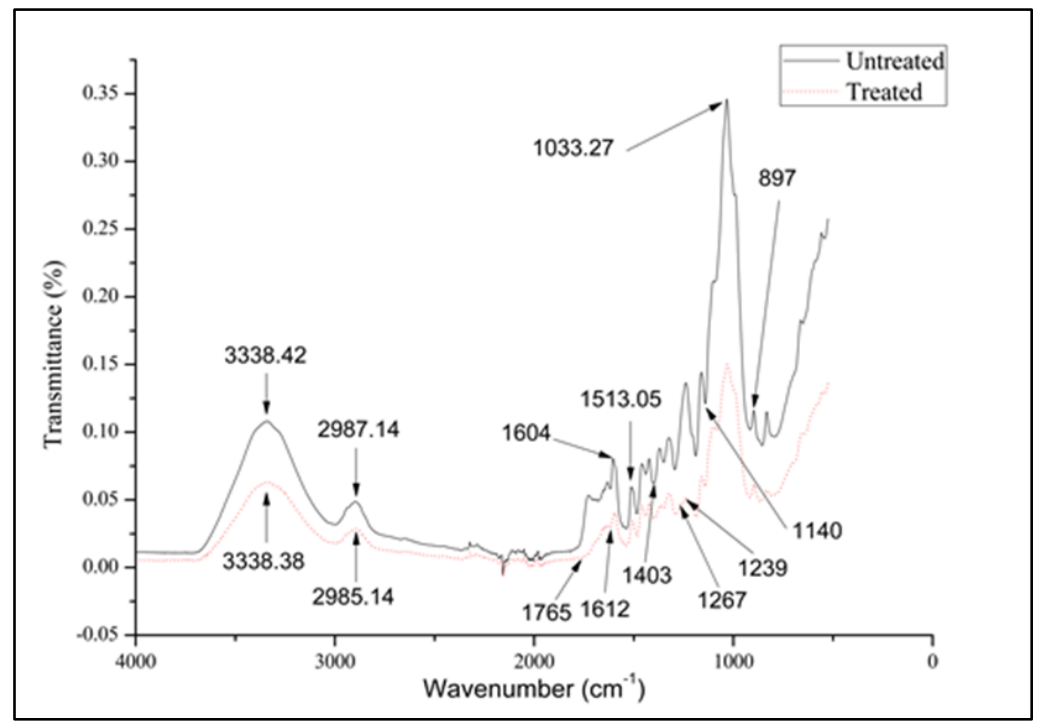

Figure 3. FTIR-ATR spectra of the alkali untreated and treated bamboo fiber

\section{Thermal analysis}

The TGA curve of raw and alkali-treated fiber is depicted in Figure 4. As can be seen from the weight loss curve, the degradation profiles of the both fibers are defined by three thermal decomposition stages. The alkalized bamboo fiber experienced minor weight loss as compared to the raw fiber. The first weight loss existed between 30 and 100 ${ }^{\circ} \mathrm{C}$, which were the moisture evaporation of the fiber. The corresponding weight loss was approximately $7 \%$. Meanwhile, the evaporation of moisture was found to be reduced in the alkali-treated fiber due to $\mathrm{NaOH}$ treatment caused a reduction in hydrophilicity of the fiber. The next degradation, so called initial degradation or onset temperature $\left(\mathrm{T}_{\text {onset }}\right)$ of the decomposition commenced in the range of $235-342{ }^{\circ} \mathrm{C}$ was mainly caused by the decomposition of the cellulose.

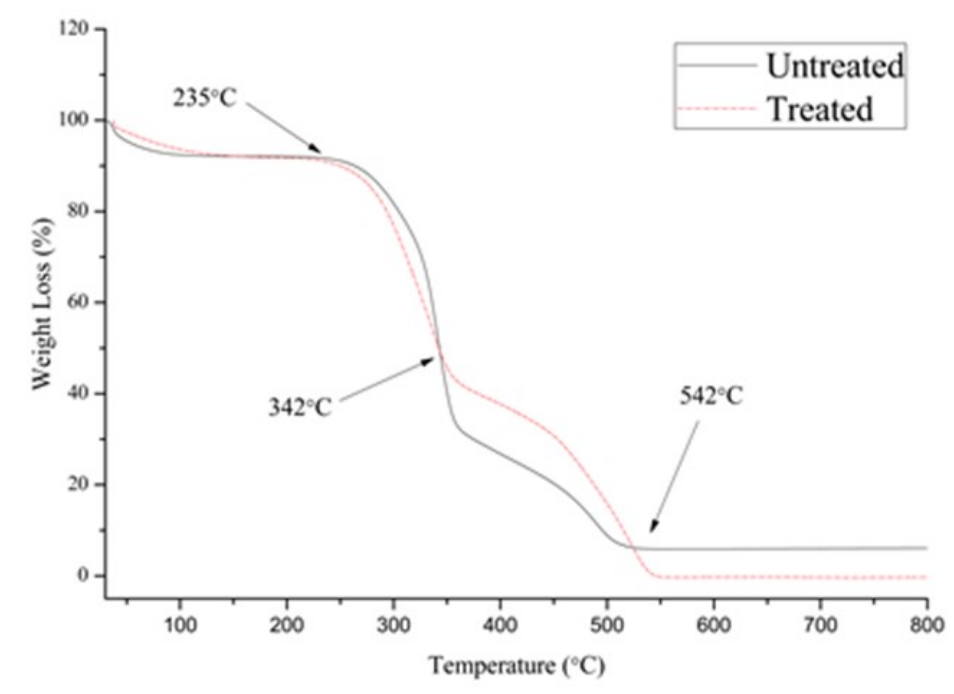

Figure 4. TGA curve of untreated and alkali treated bamboo fibers 
The degradation temperature $\left(\mathrm{T}_{\mathrm{d}}\right)$ for both raw and treated fibers was similar, which recorded at $343{ }^{\circ} \mathrm{C}$. In the following weight loss step, the decomposition of non-cellulosic materials (lignin) occurred at the lower decomposition rate and broad temperature range, from 356 to $542{ }^{\circ} \mathrm{C}$, due to lignin being difficult to decompose. The bamboo fibers were completely degraded at the temperature of approximately $542{ }^{\circ} \mathrm{C}$. The distinction in weight loss indicated the partial removal of lignin and hemicellulose materials. The overall degradation temperature of the $\mathrm{NaOH}$ treated fibers possessed a higher thermal stability. These results are almost identical to those reported elsewhere $[1,2,20]$.

\section{Conclusion}

The alkaline treatment has been identified as a significant factor for the reinforcement agent properties. FTIR analysis confirmed the removal of extractives, hemicellulose and lignin. Furthermore, no new functional group was noticed for the alkali-treated fiber. The alkaline treated fiber exhibited better thermal stability than untreated fiber, as the cementing material was removed via the alkaline treatment. Moreover, it can be associated with SEM images, where the surface smoothness of the treated fiber was better than untreated fiber. The tensile strength and modulus of the bamboo fiber were significantly improved after treated with $10 \% \mathrm{NaOH}$ treatment for 24 hours. In comparison with raw fiber, the increment in tensile strength and modulus were about 45.6 and $72 \%$, respectively. From the findings, the local abundant and economic bamboo fiber has the potential to be used as a reinforcement agent in developing composite materials for the construction industry.

\section{Acknowledgement}

This research is assisted by the Ministry of Higher Education (MOHE), Malaysia under the Research Acculturation Grant Scheme (RAGS) RDU 151409. The authors would like to express their gratitude to the Forest Research Institute of Malaysia (FRIM), Center of Excellence for Advanced Research in Fluid Flow (CARIFF), and laboratory of Faculty of Civil Engineering and Earth Resources (FKASA), University Malaysia Pahang (UMP) for the facilities and testing equipment provided.

\section{References}

1. Zhang, X., Wang, F. and Keer, L. M., (2015). Influence of surface modification on the microstructure and thermo-mechanical properties of bamboo fibers. Materials, 8: 6597 - 6608.

2. Simão, J.A., Carmona, V.B., Marconcin, J.M., Mattoso, L.H.C., Barsberg, S.T. and Sanadi, A.R. (2016). Effect of fiber treatment condition and coupling agent on the mechanical and thermal properties in highly filled composites of sugarcane bagasse fiber/pp. Materials Research, 19(4): 746 - 751.

3. Hossain, S. I., Hasan, M., Hasan, M. N. and Hassan, A. (2013). Effect of chemical treatment on physical, mechanical and thermal properties of ladies finger natural fiber. Advances in Materials Science and Engineering, 2013: 1- 7 .

4. Dalbehera, S. and Acharya, S. K. (2014). Study on mechanical properties of natural fiber reinforced woven jute -glass hybrid epoxy composites. Advances in Polymer Science and Technology: An International Journal, 4(1): $1-6$.

5. Alves, C., Ferrão, P. M. C., Silva, A. J., Reis, L. G., Freitas, M., Rodrigues, L. B. and Alves, D. E. (2010).Eco design of automotive components making use of natural jute fiber composites. Journal of Cleaner Production, 18(4): $313-327$.

6. Summerscales, J., Dissanayake, N. P. J., Virk, A. S. and Hall, W. (2010). A review of bast fibres and their composites. Part 1 - Fibres as reinforcements. Composites Part A: Applied Science and Manufacturing, 41(10): $1329-1335$.

7. Elenga, R. G., Djemia, P., Tingaud, D., Chauveau, T., Maniongui, J. G. and Dirras, G. (2013). Effects of alkali treatment on the microstructure, composition, and properties of the raffia textiles fiber. BioResources, 8(2): $2934-2949$.

8. Zakikhani, P., Zahari, R., Sultan, M. H. and Majid, D. L. (2014). Bamboo fibre extraction and its reinforced polymer composite material. International Journal of Chemical, Nuclear, Materials and Metallurgical Engineering, 8(4): $287-290$.

9. Biswas, S., Shahinur, S., Hasan, M. and Ahsan, Q. (2015). Physical, mechanical and thermal properties of jute and bamboo fiber reinforced unidirectional epoxy composites. Procedia Engineering, 105: 933 - 939. 
10. Ahmad, S., Raza, A. and Gipta, H. (2014). Mechanical properties of bamboo fibre reinforced concrete. In: 2 nd $I$ nternational conference on research in science, engineering and technology (ICRSET 2014). Dubai (UAE): pp $162-166$.

11. Vajje, S. and Murthym N. R. K. (2013) Study on addition of the natural fibers into concrete. International Jour nal of Scientific \& Technology Research, 2 (11): 213 - 218.

12. Zakikhani, P., Zahari, R., Sultan, M. T. H. and Majid, D. L. (2014). Extraction and preparation of bamboo fibre -reinforced composites. Materials and Design, 63: 820 - 828.

13. Afrin, T., Tsuzuki, T. and Wang, X. (2009). Bamboo fibres and their unique properties. Bamboo Bulletin, 11(1): $36-39$.

14. Liu, H., Huang, Y., Yuan, L., He, P., Cai, Z., Shen, Y., Xu, Y., Yu, Y. and Xiong, H. (2010). Isothermal crystallization kinetics of modified bamboo cellulose/PCL composites. Carbohydrate Polymer, 79(3): 513 519.

15. Alam, M. A., Nouri, K. and Jumaat, M. Z. (2015). Flexural strengthening of reinforced concrete beam using jute rope composite plate. In: The 3rd national Graduate conference (NatGrad2015): pp. 8 - 9.

16. Hafizah, N. A. K., Bhutta, M. A. R., Hamaludin, M. Y., Warid, M. H., Ismail, M., Rahman, M. S., Yunus, I. and Azman, M. (2014). Kenaf fiber reinforced polymer composites for strengthening RC beams. Journal of Advanced Concrete Technology, 12(6): 167 - 177.

17. Sen, T. and Jagannatha Reddy, H. N. (2014). Flexural strengthening of RC beams using natural sisal and artificial carbon and glass fabric reinforced composite system. Sustainable Cities and Society, 10: 195 - 206.

18. Okubo, K., Fujii, T. and Yamamoto, Y. (2004). Development of bamboo-based polymer composites and their mechanical properties. Composites: Part A: Applied Science and Manufacturing, 35(3): 377 - 383.

19. Ramli, R., Khan, M. M. R., Yunus, R. M., Ong, H. R., Halim, R. M., Aziz, A. A., Ibrahim, Z. and Zainal, N. H. (2014). In-situ impregnation of copper nanoparticles on palm empty fruit bunch powder. Advances in Nanoparticles, 3: 65 - 71 .

20. Chowdhury, M. N. K., Beg, M. D. H., Khan, M. R. and Mina, M. F. (2013). Modification of oil palm empty fruit bunch fibers by nanoparticle impregnation and alkali treatment. Cellulose, 20(3): 1477 - 1490. 